\title{
Estágio de docência e formação de professores na área da saúde: uma revisão
}

\section{integrativa da literatura}

\author{
Teaching internship and teacher training in health: an integrative literature review \\ Pasantía docente y formación de profesores en salud: una revisión integradora de la literatura
}

Recebido: 25/08/2021 | Revisado: 31/08/2021 | Aceito: 08/09/2021 | Publicado: 11/09/2021

Carla Rosane Paz Arruda Teo

ORCID: https://orcid.org/0000-0002-1534-6261

Universidade Comunitária da Região de Chapecó, Brasil

E-mail: carlateo@unochapeco.edu.br

\begin{abstract}
Resumo
A formação docente na educação superior em saúde é atribuição da pós-graduação stricto sensu, contexto em que o estágio de docência (ED) surge como oportunidade para atender a esta finalidade. Este estudo teve por objetivo reconhecer os limites e as potencialidades do ED na formação de professores para a educação superior em saúde. Trata-se de uma revisão integrativa de literatura na qual foram incluídos oito artigos publicados a partir de 2015 . Foi realizada análise de conteúdo temática, a partir das seguintes categorias: fragilidades, desafios, potências, oportunidades do ED. Constatou-se, como fragilidades, que o ED é apresentado como lugar da prática, de inquietações práticas e de desvios de finalidade, produzindo ideias da docência como atividade simples. Os desafios identificados foram: centralidade da pesquisa na pós-graduação, docência tecnicista, conteudista e transmissiva, incipiente formação pedagógica e orientada para o SUS, formação docente como capacitação, indefinição de papeis e de perfil docente, irrelevância no sistema de avaliação da pós-graduação. As potências indicadas foram: ED como lugar da experiência, de relações interpessoais, de apropriação operativa da docência, de contribuições do estagiário. Como oportunidades, foram observadas: ED como lugar de aprendizagem, de reflexão crítica sobre a prática, de formação docente como processo, de formação docente ampliada, de articulação ensino-pesquisa-extensão, flexibilidade normativa. Conclui-se que a docência reclama por priorização na pós-graduação, e que produzir novos e robustos conhecimentos sobre o ED contribuirá para a formação de professores comprometidos com a consolidação e o fortalecimento do SUS por meio da qualificação da educação superior em saúde.
\end{abstract}

Palavras-chave: Docentes; Educação superior; Educação de pós-graduação; Ensino; Programas de pós-graduação em saúde.

\begin{abstract}
Teacher training in higher education in health is responsibility of graduate studies, and the teaching internship (TI) appears as an opportunity to meet this purpose. This study aimed to recognize the limits and potential of TI in teachers training for higher education in health. This is an integrative literature review which included eight articles published from 2015 on. Thematic content analysis was carried out, based on the following categories: weaknesses, challenges, strengths, opportunities in TI. It was found, as weaknesses, that the TI is presented as a place of practice, of practical concerns and purpose deviations, producing ideas of teaching as a simple activity. The challenges identified were: research centrality in graduate studies, teaching process centered on technical content transmission, incipient pedagogical training and oriented towards SUS, limited teacher training, lack of definition on roles and teacher profile, irrelevance in the postgraduate assessment system. The indicated strengths were: TI as a place of experience, interpersonal relationships, operative appropriation of teaching, trainee's contributions. As opportunities, the following were observed: TI as a place of learning, critical reflection on practice, teacher training as a process, expanded teacher training, teaching-research-extension articulation, normative flexibility. It is concluded that teaching demands prioritization in graduate studies, and that producing new and robust knowledge about TI will contribute for training committed teachers on consolidating and strengthening SUS through the qualification of higher education in health.
\end{abstract}

Keywords: Faculty; Education, higher; Education, graduate; Teaching; Health postgraduate programs.

\section{Resumen}

La formación del profesorado en la educación superior en salud es responsabilidad de posgrado, y la pasantía docente (PD) aparece como una oportunidad para cumplir con este propósito. Este estudio tuvo como objetivo reconocer límites y potencialidades de la PD en la formación de profesores de educación superior en salud. Se trata de una revisión integradora de la literatura que incluyó ocho artículos publicados a partir de 2015. Se realizó un análisis de contenido temático, con base en las categorías: debilidades, desafíos, fortalezas, oportunidades en PD. Se constató, como debilidades, que la PD se presenta como un lugar de práctica, de inquietudes prácticas y desviaciones de 
propósito, produciendo ideas de docencia como una actividad simple. Los desafíos identificados fueron: centralidad de la investigación en estudios de posgrado, docencia técnica y de transmisión, formación pedagógica incipiente y orientada hacia el SUS, formación como capacitación, indefinición de roles y perfil docente, irrelevancia en la evaluación de posgrados. Las fortalezas señaladas fueron: PD como lugar de experiencia, de relaciones interpersonales, de apropiación operativa de docencia, de aportes del aprendiz. Como oportunidades, se observaron las siguientes: PD como lugar de aprendizaje, de reflexión crítica sobre la práctica, de formación docente como proceso y ampliada, de articulación enseñanza-investigación-extensión, flexibilidad normativa. Se concluye que la docencia debe ser priorizada en posgrado, que producir nuevos y robustos conocimientos sobre PD contribuirá a la formación de docentes comprometidos con la consolidación y fortalecimiento del SUS a través de la calificación de la educación superior en salud.

Palabras clave: Docentes; Educación superior; Educación de postgrado; Enseñanza; Programas de posgrado en salud.

\section{Introduçãa}

O Sistema Único de Saúde (SUS), edificado sobre os princípios da universalidade, equidade e integralidade, tem recebido visibilidade - em tempos de pandemia, talvez mais do que em qualquer outro período -, sendo reconhecido em sua imprescindibilidade para o enfrentamento da desigualdade social no país ao contribuir para assegurar à população um de seus direitos mais elementares - o direito à saúde.

A criação do SUS representou um marco na reorientação do modelo de atenção à saúde no Brasil e, como consequência, exigiu a reorientação do modelo de formação de profissionais para atuarem nesse sistema. Para tanto, a Constituição Federal (Brasil, 1988) e, posteriormente, a Lei Orgânica de Saúde n. 8.080 (Brasil, 1990) definiram o SUS como ordenador da formação de profissionais da área da saúde. Estas disposições se desdobraram, ao longo do tempo, em diversas iniciativas na interface saúde-educação, com vistas a provocar mudanças na formação consonantes aos princípios e diretrizes do SUS.

De imediato, o desdobramento a ser destacado se refere à criação das Diretrizes Curriculares Nacionais (DCN) para os cursos de graduação da área da saúde, que começaram a ser publicadas a partir de 2001 (Brasil, 2001a, 2001b, 2001c). A seguir, duas outras iniciativas merecem ser sublinhadas: o Programa Nacional de Reorientação da Formação Profissional em Saúde (PRÓ-Saúde) e o Programa de Educação pelo Trabalho para a Saúde (PET-Saúde). Estas, entre outras estratégias, foram implantadas a partir de uma pareceria entre os Ministérios da Saúde e da Educação com o propósito de estimular a integração ensino-serviço-comunidade, assumindo a premissa do SUS como escola, como cenário de formação profissional inicial, continuada e permanente, sobre as bases da unidade teoria-prática, com vistas à construção de um perfil profissional generalista, humanista, autônomo, crítico, reflexivo, com visão integral do humano e do processo saúde-adoecimento, preparado para atuar colaborativamente e pautado em princípios éticos (Brasil, 2005, 2008).

Contudo, neste percurso, parece restar uma lacuna: e o professor, a professora? O que dizem o marco legal do SUS e as políticas de reorientação da formação de profissionais de saúde sobre quem forma estes profissionais? Qual é o perfil docente para a formação profissional em saúde? Quem forma esse professor? A esse respeito, três questões precisam ser registradas. Primeira: não há, nas políticas mencionadas, explicitação sobre o perfil docente esperado e sobre a formação de professores para a área. Segunda: as proposições das políticas públicas da interface saúde-educação, no que tange ao processo ensino-aprendizagem pretendido, parecem sugerir um perfil docente problematizador, flexível, dialógico e capaz de mobilizar o estudante para assumir-se como ativo no processo de aprender e desenvolver-se (Alves \& Teo, 2020). Terceira: na educação superior em saúde, geralmente, um profissional torna-se professor pela atuação de excelência em uma área disciplinar específica, sem qualquer formação docente prévia (Freitas et al., 2016).

Essas constatações respaldam a ponderação de que há, aí, uma lacuna a ser explorada. Afinal, como ensina Freire (1991, p. 58), "Ninguém começa a ser educador numa certa terça-feira às quatro da tarde. Ninguém nasce educador ou marcado para ser educador. A gente se faz educador, a gente se forma, como educador, permanentemente, na prática e na 
reflexão sobre a prática." Isso não significa dizer que a formação do professor é um processo que se desenvolva espontaneamente. Pelo contrário, a reflexão sobre a prática requer intencionalidade e teorização para que possa constituir, efetivamente, um processo formativo. Neste sentido, é Freire quem, novamente, elucida que ensinar é uma especificidade humana que requer, entre tantos outros, o saber do comprometimento com a própria competência profissional. Esse comprometimento revela, inclusive, uma atitude ética com o ato de formação (Freire, 2016).

Explorando a lacuna apontada, pode-se localizar uma orientação sobre a formação de professores para a educação superior em geral na Lei de Diretrizes e Bases da Educação Nacional (LDBEN), que estabelece que "A preparação para o exercício do magistério superior far-se-á em nível de pós-graduação, prioritariamente em programas de mestrado e doutorado." (Brasil, 2020a, artigo 66). Já o Plano Nacional de Pós-Graduação (PNPG) 2011-2020 (Brasil, 2010a) e seus relatórios periódicos de acompanhamento tratam do tema da formação de professores para a educação superior (e de seu sucesso) em termos basicamente quantitativos, considerando a titulação acadêmica de mestres e doutores como indicador de capacitação docente (Brasil, 2020b). Posição similar é adotada pelo Instituto Nacional de Estudos e Pesquisas Educacionais Anísio Teixeira (INEP) ao tratar da avaliação da educação superior no país (Brasil, 2017a).

Outro indicativo sobre o tema pode ser localizado em documentos da Coordenação de Aperfeiçoamento de Pessoal de Nível Superior (CAPES), que instituiu, em 1999, o Estágio de Docência (ED) no âmbito da pós-graduação stricto sensu (Brasil, 1999). Desde então, com algumas variações, diversos outros documentos da CAPES têm reforçado o ED como componente da formação pós-graduada, visando à preparação para a docência e à qualificação do ensino de graduação, estabelecendo sua obrigatoriedade para doutorandos (ou, eventualmente, para mestrandos) bolsistas que não possuam experiência comprovada como professores no ensino superior (Brasil, 2002, 2010b, 2012, 2017b).

Diante do contexto brevemente apresentado, pondera-se que, frente à lacuna relativa à formação docente para a educação superior em saúde no escopo das políticas públicas dessa área, o ED surge, no âmbito da pós-graduação stricto sensu, como rara oportunidade institucionalizada para a formação de professores universitários. Nesse ponto, pergunta-se: em que medida o estágio de docência, conforme vem sendo desenvolvido, contribui efetivamente para a formação docente na área da saúde? Quais são seus limites e potencialidades?

É na busca por respostas para estas perguntas que este texto se constitui, tendo por objetivo reconhecer os limites e as potencialidades do estágio de docência na formação de professores para a educação superior em saúde. Nesta dinâmica, o texto está organizado por meio desta seção introdutória, seguida por uma metodológica, uma de apresentação e discussão dos achados e uma última, em que são tecidas algumas considerações finais.

\section{Metodologia}

Para atender ao objetivo declarado, foi realizada uma pesquisa documental de base bibliográfica, conforme os pressupostos da Revisão Integrativa de Literatura (Ganong, 1987). A busca da literatura foi realizada no dia 03 de julho de 2021, nas seguintes plataformas: Portal de Periódicos CAPES, Portal Brasileiro de Publicações Científicas em Acesso Aberto/oasisbr, Repositórios Científicos de Acesso Aberto de Portugal (RCAAP), Biblioteca Virtual em Saúde (BVS), Scientific Electronic Library Online (SciELO), Red de Revistas Científicas de América Latina y el Caribe, España y Portugal (redalyc) e Biblioteca Digital Brasileira de Teses e Dissertações (BDTD). A estratégia de busca utilizada foi: ((estágio de docência) $O R$ (estágio em docência) $O R$ (estágio na docência) $O R$ (estágio docência) $O R$ (estágio docente)).

No processo de busca dos estudos, foram estabelecidos os seguintes critérios de inclusão iniciais: trabalhos publicados a partir de 2015 (inclusive), no formato de artigos, dissertações e teses, nos idiomas inglês, português e espanhol, disponíveis online em texto completo de acesso aberto. No processo de seleção dos estudos, foram, a princípio, removidas as duplicatas e, a seguir, aplicados dois critérios de inclusão adicionais: tratar do objeto de estudo (estágio de docência) na área da saúde e no 
âmbito da pós-graduação stricto sensu. Aos estudos elegíveis assim identificados, foi aplicado um último critério de inclusão, relativo à aderência ao objeto de estudo.

A busca nos portais indicados localizou 181 artigos e 25 dissertações, os quais, após a remoção das duplicatas, resultaram em 148 artigos e oito dissertações. Os títulos e resumos destes estudos foram lidos e, da aplicação dos critérios de inclusão adicionais, restaram 11 artigos completos para serem lidos na íntegra. Da aplicação do critério de inclusão final, resultaram oito estudos incluídos nesta revisão. O fluxograma detalhado do processo de composição do corpus de pesquisa é apresentado na Figura 1.

Figura 1. Fluxograma do processo de composição do corpus do estudo.

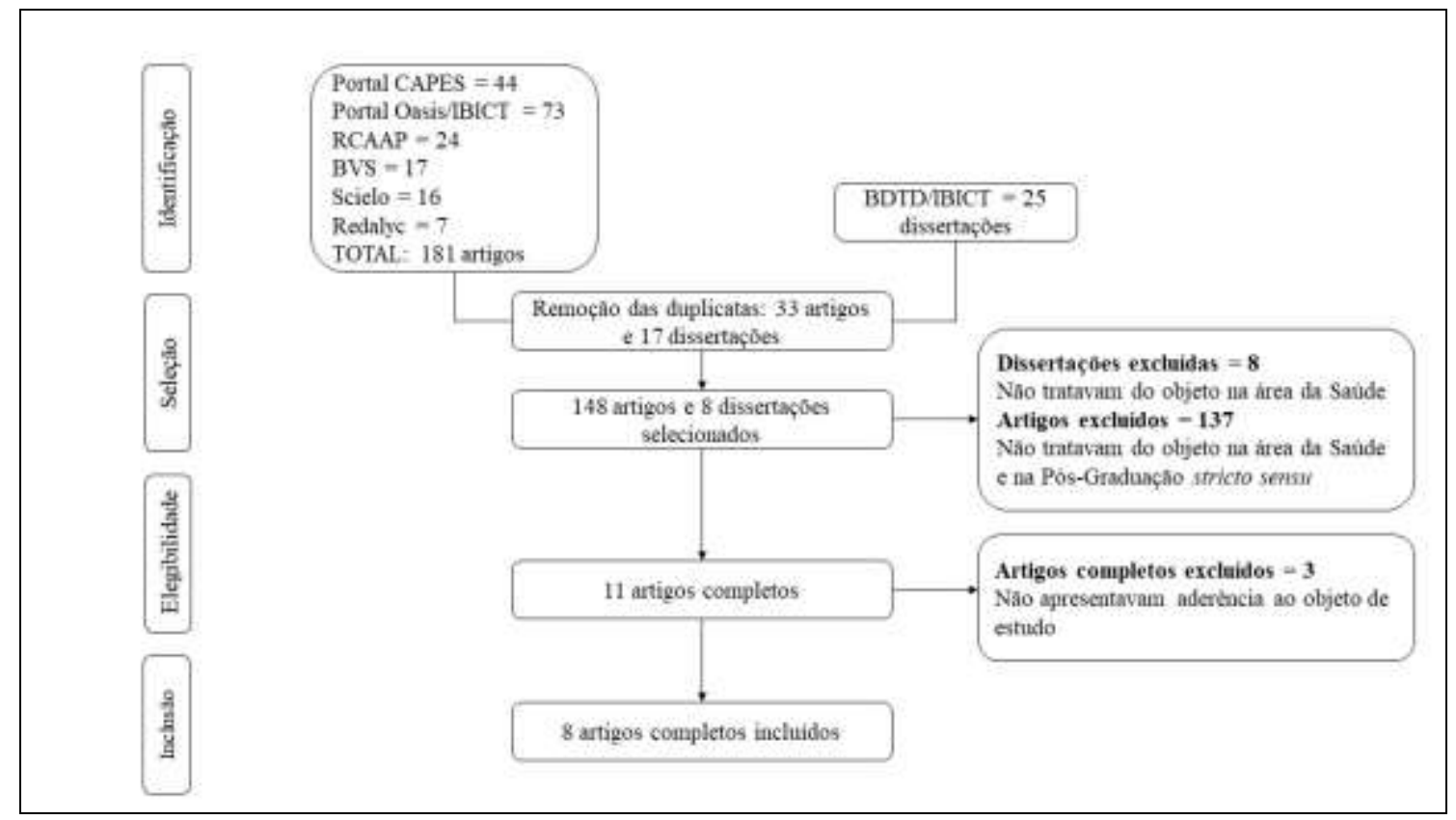

Fonte: Elaboração da autora (2021).

Uma vez configurado o corpus de estudo (Quadro 1), foi realizada nova leitura na íntegra dos oito artigos incluídos, agora em profundidade, coletando-se os dados e informações de interesse para o estudo (autores, ano e periódico de publicação, objetivos, metodologia, principais resultados e conclusões), que foram organizados em uma matriz analítica em arquivo do Microsoft Word $^{\circledR}$. A partir desta matriz analítica, foram elaboradas, inicialmente, uma caracterização do corpus de pesquisa e uma síntese narrativa sobre o objeto de estudo. Esta síntese representa o material que foi explorado, procedendo-se à Análise de Conteúdo Temática (Minayo, 2014) que, em acordo com o objetivo deste estudo, foi orientada pelas seguintes categorias analíticas prévias: potências, fragilidades, desafios e oportunidades do ED para a formação docente na área da saúde. 
Quadro 1. Publicações incluídas no corpus do estudo sobre estágio de docência.

\begin{tabular}{|cl}
\hline Código & \multicolumn{1}{c}{ Dados de Publicação } \\
A1 & $\begin{array}{l}\text { Lima, M. M., Vendruscolo, C., Prado, M. L., \& Reibnitz, K. S. (2015). Estágio de docência na construção de saberes para } \\
\text { ensinar: revisão integrativa. Revista de enfermagem UFPE on line, 9(1), 220-227. }\end{array}$ \\
A2 & $\begin{array}{l}\text { Ribeiro, G. M., \& Zanchet, B. M. B. A. (2015). Estágio de docência: possibilidades e limites na formação de professores } \\
\text { universitários. Currículo sem Fronteiras, 15(2), 508-526. }\end{array}$ \\
A3 & $\begin{array}{l}\text { Friestino, J. K. O., Ferraz, R. O., Fialho, P. M. M., \& Corrêa, C. R. S. (2015). A docência como eixo formador de doutores } \\
\text { em saúde coletiva: contribuição do estágio docente. Revista UNIABEU, 8(20), 325-336. }\end{array}$ \\
A4 & $\begin{array}{l}\text { Braga, N. L., Pinheiro, N. P., \& Feitosa, L. B. (2016). Estágio em docência: o relato de experiência como recurso necessário } \\
\text { na avaliação da aprendizagem. Caminho Aberto - Revista de Extensão do IFSC, 3(5), 66-70. }\end{array}$ \\
A5 & $\begin{array}{l}\text { Alves, L. R., Giacomini, M. A., Teixeira, V. M., Henriques, S. H., \& Chaves, L. D. P. (2019). Reflections on graduate } \\
\text { professor training. Escola Anna Nery, 23(3), e20180366. }\end{array}$ \\
An6 & $\begin{array}{l}\text { Angelim, R. C. M., Brandão, B. M. G. M., Pereira, V. M. A. O., Freire, D. A., \& Abrão, F. M. S. (2019). Educação à } \\
\text { distância no ensino superior: relato de experiência em estágio de docência. Revista de Enfermagem do Centro Oeste }\end{array}$ \\
& $\begin{array}{l}\text { Mineiro, 9, e2672. } \\
\text { Amorim, T. R. S., Pessoa, M. C. B., \& Alberto, M. F. P. (2020). Aprendendo a Ser Docente: Relato de Experiência em }\end{array}$ \\
& $\begin{array}{l}\text { Estágio de Docência. Gerais: Revista Interinstitucional de Psicologia, 13(3), e15241. } \\
\text { A8 }\end{array} \quad \begin{array}{l}\text { Freitas, E. N. B., \& Ribeiro, M. L. (2021). O estágio de docência nas representações de estudantes de saúde coletiva. Temas } \\
\text { em Educação e Saúde, 17(00), e021006. }\end{array}$
\end{tabular}

Fonte: Elaboração da autora (2021).

Convém, nesse ponto, elucidar o que se assume como definição das categorias supracitadas. Potências são tomadas como características vantajosas ou aspectos positivos consolidados que, no caso em tela, favorecem e qualificam o ED como espaço de formação docente. Fragilidades são pontos fracos ou aspectos negativos que representam desvantagens para o processo de formação docente no âmbito do ED. Desafios são, aqui, entendidos como questões estruturais ou consolidadas na prática social e que comprometem, limitam ou impedem que o ED cumpra plenamente sua finalidade no processo de formação docente. Oportunidades são potências em estado latente que precisam superar a condição de eventuais pela de instaladas, de forma que o ED seja qualificado em sua finalidade de formação docente. Em síntese, isso significa dizer que as categorias elencadas para análise do ED se referem a aspectos positivos e negativos, assim como a obstáculos a serem enfrentados e a possibilidades a serem consolidadas. Tendo em vista o objetivo deste estudo, as fragilidades e os desafios são indicadores dos limites do ED na formação de professores para a educação superior em saúde, enquanto as potências e as oportunidades expressam suas potencialidades. Na discussão construída, os achados da análise foram cotejados, especialmente, com o referencial teórico freireano. Apresenta-se, a seguir, o material explorado neste estudo.

\subsection{Caracterização do corpus de estudo}

Os oito artigos incluídos nesta revisão (Quadro 1) contemplam uma abordagem qualitativa de pesquisa, sendo três relatos de experiência (A4, A6, A7), um ensaio reflexivo (A5), duas pesquisas documentais - uma com base bibliográfica (A1) e uma com base em relatórios finais de ED (A3) - e duas pesquisas descritivas, com base em entrevistas semiestruturadas aplicadas a sujeitos que concluíram ED na pós-graduação (A2, A8).

Com relação ao ano de publicação, metade dos artigos incluídos no corpus de estudo (n=4) foi publicada em 20152016 e a outra metade $(n=4)$, em 2019-2021, não tendo sido selecionadas publicações do biênio 2017-2018. Os artigos foram publicados por oito diferentes periódicos científicos das regiões Nordeste $(n=1)$, Sul $(n=2)$ e Sudeste $(n=5)$ do Brasil, das áreas da enfermagem ( $\mathrm{n}=3$ ), psicologia $(\mathrm{n}=1)$ e interdisciplinar $(\mathrm{n}=4)$, classificados pelo Qualis CAPES vigente como $\mathrm{B} 1(\mathrm{n}=2), \mathrm{B} 2$ $(n=1)$ e $B 4(n=5)$. 
Os estudos analisados tiveram objetivos orientados a analisar a contribuição do ED para a construção dos saberes profissionais (A1), perceber em que medida o ED contribui ou se coloca como uma oportunidade para a construção de conhecimentos para a docência universitária (A2), identificar as contribuições da experiência docente e o significado do estágio para a formação de doutores (A3), relatar, descrever e refletir sobre a experiência de estágio e a formação docente por ela proporcionada (A4, A5, A6, A7) e desvelar as representações de mestrandos sobre o ED (A8).

Ao tratarem da formação docente, os artigos analisados adotaram diferentes referenciais teóricos, tendo predominado os autores Paulo Freire (A2, A7, A8), Maurice Tardif (A1, A5, A8), Maria Isabel da Cunha (A2, A3, A7), Selma Garrido Pimenta (A2, A3, A8), Lea das Graças Camargos Anastasiou (A2, A3) e Marcos Tarciso Masetto (A2, A7). Além destes, outros autores foram, com menor frequência, assumidos como base teórica para os artigos incluídos nesta revisão, como Lev Semionovitch Vigotski, Dermeval Saviani, Ana Carolina Galvão Marsiglia, Angelo Antonio Abrantes e Larissa Bulhões (A7), António Manuel Seixas Sampaio da Nóvoa e Miguel Angel Zabalza (A8), Ilma Passos Alencastro Veiga (A2) e Philippe Perrenoud (A5).

Em síntese, pondera-se que há relativa escassez de estudos sobre a temática da formação docente na área da saúde a partir do ED, o que é corroborado pelo estudo de Lima et al. (2015), incluído no corpus desta revisão (A1). As autoras, ao realizarem uma revisão integrativa da literatura referente ao período de 2002 a 2012, também localizaram oito estudos para análise. Essa escassez parece indicar que o ED permanece, em alguma medida, inexplorado sob a delimitação aqui proposta a formação docente na saúde.

Estas considerações são reforçadas pela constatação de que, no presente estudo, metade dos artigos analisados correspondem a relatos de experiência e ensaios reflexivos. Esta observação sugere ser ainda menor a assunção do ED, per se, como objeto de pesquisas. Contudo, considerando o corpus de estudo em sua totalidade, argumenta-se que os objetivos dos artigos analisados revelam que a questão da formação docente na área da saúde é instigante e que o ED precisa ser colocado em debate no que tange a sua contribuição em potencial para esse processo.

No âmbito dessa abordagem, destaca-se que os artigos analisados apresentam, predominantemente, um referencial teórico do campo das teorias educacionais críticas, o que, a nosso juízo, é um elemento importante para o enfrentamento e a superação das lacunas da formação docente na área da saúde, visto a consonância destas teorias com a essência do movimento da Reforma Sanitária que culminou na criação do SUS.

Dada esta caracterização, apresenta-se, a seguir, uma síntese narrativa do conteúdo dos estudos selecionados.

\subsection{Sobre o estágio de docência: uma síntese a partir do corpus de estudo}

Em A1, da análise dos oito estudos selecionados para revisão de literatura, emergiram duas categorias temáticas. No âmbito da primeira delas - aproximação do pós-graduando com os diversos contextos da prática docente -, as autoras referem que as publicações encontradas indicam relativa contribuição do ED para a qualificação de pós-graduandos, destacando novas possibilidades metodológicas para o ensino, reflexão sobre a prática, importância do professor supervisor, compreensão do papel docente de mediador e de que ensinar não pode estar restrito a transmitir conhecimentos. O ED surge, dos estudos analisados, como potência de integração da graduação com a pós-graduação, sendo indicado que deve contemplar a participação do estagiário desde o planejamento da disciplina. O ED também é apontado como possibilidade de espaço de pesquisa, isto é, para coleta de dados para o pós-graduando. Faz-se a ressalva de que é preciso superar a ideia de que a pesquisa é a essência do trabalho docente, deslocando o foco para a necessária integração ensino-extensão-pesquisa na educação superior em saúde (Lima et al., 2015).

Na segunda categoria temática - construção de saberes profissionais docentes no estágio de docência -, os estudos analisados demonstram que o ED, ao propiciar a vivência da prática pedagógica, a aproximação e o (re)conhecimento de 
metodologias inovadoras de ensino-aprendizagem, oportuniza ao pós-graduando a construção de saberes profissionais para o exercício docente. É salientada, também, a importância de que as vivências no ED estejam pautadas por um movimento de debate e reflexão sobre os princípios teóricos da educação. Sugere-se que a prática pedagógica crítica e reflexiva influencia a construção de saberes profissionais dos pós-graduandos, integrando graduação e pós-graduação. A título de finalização, as autoras registram a pouca divulgação do ED na literatura científica, creditando esse achado à importância conferida à pesquisa em detrimento da formação docente (Lima et al., 2015).

Em A2, foram aplicadas entrevistas semiestruturadas a 15 professores do ensino superior que, quando pósgraduandos, realizaram ED. A partir da análise de conteúdo do material textual resultante das entrevistas, as autoras afirmam que os participantes apresentavam concepções de ensino como transmissão de informação (a mais recorrente), como capacitação para a aprendizagem, e como troca/construção coletiva. Já a prática pedagógica foi, predominantemente, compreendida em sua dimensão objetiva, materializada nos modos, meios e instrumentos pelos quais a docência é exercida. Na realidade do programa de pós-graduação em que desenvolveram o ED, os participantes o referiram como atividade de orientação de pesquisas e de execução de tarefas predeterminadas, tendo, por consequência, percebido seu papel de estagiário como sendo, principalmente, o de orientar o trabalho de campo dos estudantes da graduação, levando-os a serem reconhecidos por eles como monitores (Ribeiro \& Zanchet, 2015).

Em contraponto, os entrevistados revelaram que suas expectativas com o ED eram de que essa experiência oportunizaria o aprendizado sobre a docência, abordada também em sua dimensão teórica. Além disso, foi relatado receio sobre o domínio do conteúdo necessário e sobre a receptividade dos estudantes da graduação. Os participantes ainda mencionaram, como dificuldades enfrentadas, a participação restrita às aulas teóricas da disciplina, a não participação no planejamento das aulas, a falta de embasamento teórico sobre a docência, a ausência de orientação para as atividades docentes, a falta de autonomia no decorrer do ED e o fato de, segundo eles, o estágio se caracterizar principalmente como atividade de orientação de pesquisas. No entanto, consideraram o ED uma atividade formativa importante, que possibilita aproximação com a docência e com os estudantes da graduação (Ribeiro \& Zanchet, 2015).

Também foram reconhecidas algumas limitações do ED, tais como a falta de parâmetros normativos mais específicos para o estágio e sua excessiva flexibilidade de execução, além de uma percepção de irrelevância do ED no sistema de avaliação da pós-graduação e de que há professores que não valorizam a atividade docente. Essas questões levaram os participantes a considerar que o estágio não os preparou efetivamente para a docência, tendo ficado muito aquém do esperado. Por outro lado, também foram reconhecidas contribuições do ED: proporciona as primeiras aprendizagens na docência; desenvolve habilidade de reconhecer comportamentos e interesses dos estudantes na aula, assim como a de organizar trabalhos em grupos; possibilita aprendizagens quanto à avaliação (individual e de grupos); promove o reconhecimento da importância de manter uma postura de diálogo com os graduandos. Com base no exposto, foram apresentadas sugestões para qualificar o ED, incluindo embasamento teórico e oferta de disciplinas teóricas voltadas à formação de professores na pós-graduação, que contemplem conteúdos que tratem de modelos de educação, planejamento de ensino, didática, métodos e técnicas de ensino e de avaliação (Ribeiro \& Zanchet, 2015).

Em A3, foi desenvolvida uma pesquisa documental que tomou como fonte de dados três relatórios finais de ED elaborados em livre-expressão por doutorandos, com o propósito de descrever a experiência e sua contribuição para a formação como doutor. A análise de discurso destes materiais indicou que o ED foi percebido como promotor de desenvolvimento didático e aprendizado sobre como lidar com os estudantes de graduação. Os relatórios revelaram uma percepção de aprender enquanto ensina, embora ainda muito ligada ao conteúdo em si e não à docência como uma prática social. Contudo, os pósgraduandos manifestaram sentir falta de uma definição mais explícita dos papéis do estagiário e do professor no processo ensino-aprendizagem, reconhecendo-se como coadjuvantes e indicando uma necessidade de se constituírem como sujeitos 
responsáveis pelo processo. Finalmente, os pós-graduandos expressaram, em seus relatórios, uma valorização da experiência do ED para sua formação individual na pós-graduação, com desenvolvimento pessoal e superação de dificuldades dadas, por exemplo, pela timidez e pela falta de experiência docente (Friestino et al., 2015).

O estudo A4 é um relato descritivo do ED de duas mestrandas, que registraram que a troca de experiências entre elas, os estudantes de graduação e o professor da disciplina proporcionou crescimento e aprendizado a todos. Assim, as autoras ponderaram que o ED é uma importante etapa do processo de formação do estudante da pós-graduação, contribuindo para o aprendizado prático do exercício de ser professor. Entre as questões desafiadoras, o relato destaca a necessidade de organização do tempo, visto que o mestrado implica, simultaneamente, uma série de outras atividades para além do ED, e uma dificuldade relacionada à habilidade de falar em público, o que exige desinibição, didática, boa oratória e capacidade de articulação entre teoria e prática. Na experiência relatada, a estratégia utilizada pelas autoras para a superação das dificuldades foi desenvolver um bom plano de aula, treinar e revisar o conteúdo e as aulas planejadas, buscar informações atualizadas e trocar com outros estagiários e com professores, além de utilizar metodologias criativas e participativas para conferir sentido e impulsionar a participação dos graduandos nas atividades (Braga et al., 2016).

Já A5 é um ensaio reflexivo em que é salientada a importância, oportunizada na pós-graduação, da interface entre a formação em uma área específica e a particularidade da formação de professores, que exige referenciais próprios. Por este motivo, as autoras consideram desafiadora a questão de que, no Brasil, a ênfase da pós-graduação seja a formação de pesquisadores, o que faz com que pós-graduandos se tornem professores da educação superior sem que tenham formação pedagógica adequada e pautada pela realidade do sistema de saúde. As autoras sublinham que é um equívoco (a ser superado) o entendimento de que a competência científica certificada pela pós-graduação contempla a competência pedagógica. Isso embasa a ponderação de que o ED é uma potente estratégia, a despeito de seus limites, para oferecer desenvolvimento docente a mestres e doutores (Alves et al., 2019).

As autoras desenvolvem seu ensaio reflexivo com base em uma experiência de ED cuja normatização prevê a frequência prévia a uma disciplina pedagógica preparatória. Esse contexto é considerado favorecedor de uma posterior inserção mais qualificada no ED propriamente dito, visto que as pós-graduandas construíram recursos para refletir sobre a práxis docente. Esse formato, segundo as autoras, também promove a discussão sobre o que pode ser melhorado, numa abordagem ação-reflexão-ação que contribui para uma aprendizagem docente significativa. Em síntese, o ED, vinculado à preparação pedagógica anterior, é percebido como suporte para a prática. Contudo, as autoras salientam que é preciso atentar para a questão dos papeis, uma vez que o pós-graduando estagiário não está, no ED, na posição de estudante, mas também não é visto como professor da disciplina em que está inserido. Então, o pós-graduando pode transitar desde a visão do professor até a do graduando, em um exercício de apreensão da complexidade da relação ensino-aprendizagem, que é um processo relacional, comunicativo e de aprendizagem para os três atores envolvidos, permeado por uma inquietação sobre os papéis assumidos. Nessa perspectiva, a depender da qualidade das interações estabelecidas, o ED pode representar uma possibilidade ativa de aprendizagem não só para o pós-graduando como também para o professor. As autoras ainda alertam para a natureza contínua da formação docente, que não se esgota no estágio, de forma que o estagiário esteja empenhado em evitar assumir o papel de replicador de conteúdos (Alves et al., 2019).

De acordo com a experiência vivenciada pelas autoras, em sendo realizado com supervisão do orientador de pósgraduação, o ED pode contribuir também para o processo mesmo de orientação do pós-graduando, ao favorecer a articulação ensino-pesquisa. Essa articulação se refere não só ao tema de pesquisa do pós-graduando, mas também como possibilidade de fortalecer a prática baseada em evidências, a percepção da relevância da atualização para a prática docente e o acesso a diferentes fontes bibliográficas. Dito de outro modo, o orientador, ao supervisionar o ED de seus orientandos, pode contribuir para a valorização do consumo da pesquisa e de sua incorporação na prática docente. Esta perspectiva, ao se ampliar para o 
estagiário, pode suscitar a problematização sobre como reforçar a relevância de seu próprio projeto de pesquisa. Ademais, as autoras recomendam uma maior participação dos pós-graduandos estagiários na preparação das aulas teóricas, no âmbito do $\mathrm{ED}$, visto que eles podem compartilhar aprendizagens conquistadas na fase preparatória, contribuindo para a formação permanente do professor da disciplina (Alves et al., 2019).

A6 é um relato de experiência sobre o ED realizado por duas mestrandas, desenvolvido no formato de tutoria na modalidade de educação a distância $(\mathrm{EaD})$ com estudantes de graduação. As autoras referiram o ED como uma aproximação com o processo de ensino-aprendizagem, que representou uma oportunidade para discutir conteúdos teóricos e aplicá-los à prática supervisionada da docência. Também foi ressaltado que o ED no formato EaD constituiu uma experiência diferenciada importante, visto que esta modalidade vem se tornando frequente na graduação, como ferramenta de apoio ao ensino presencial. Em se tratando da experiência de tutoria (na modalidade $\mathrm{EaD}$ ), as autoras consideraram que foi uma abordagem inovadora com potencial para promover maior interação entre estudante e professor, já que ambos passam a desempenhar um papel mais ativo no processo ensino-aprendizagem (Angelim et al., 2019).

Em A7, é apresentado um relato de experiência em ED resultante da reflexão sobre a ação, desenvolvida em parceria pelas estudantes de pós-graduação com a professora da disciplina. A experiência de ED orientou-se pela premissa de que a atividade-guia do adolescente/jovem é a contradição entre a atividade de estudo profissionalizante e a atividade produtiva, e, a partir daí, foram consideradas, na condução da disciplina de graduação, possibilidades de atuação (trabalho) em situações reais. Foi salientada a necessidade de que as pós-graduandas em estágio estudassem muito, preparando-se para as atividades da disciplina, enquanto, por outro lado, tinham clareza da importância de que fosse superada a perspectiva conteudista. As autoras referiram a inquietação sobre como promover a participação dos estudantes nas aulas e, nesse sentido, o aprendizado sobre a importância de, para isso, considerar a realidade dos estudantes, colocando-os em situações que poderiam emergir na prática como futuros profissionais. As estagiárias relataram as seguintes estratégias: estudar o conteúdo a partir de diversos textos, além dos indicados para os estudantes; atentar para o uso de recursos visuais como apoio e não como protagonistas da aula; utilizar disparadores da discussão em sala de aula relacionados aos conteúdos, como notícias de jornal e charges; iniciar as aulas sempre pela escuta dos educandos, convocando-os a enunciar o que sabiam sobre o tema da aula; criar um ambiente favorável à discussão, respeitando os diferentes posicionamentos (Amorim et al., 2020).

Entre os desafios apontados, as pós-graduandas mencionaram a avaliação, tanto sua elaboração com vistas aos objetivos da disciplina quanto sua correção. Assim, as avaliações foram inteiramente tratadas em conjunto pelas estagiárias com a professora da disciplina, como recurso de aprendizagem docente. Ainda, na ausência da professora da disciplina, a autoridade das estagiárias chegou a ser questionada pelos estudantes, desafio que foi superado pela pactuação de um acordo de convivência, na direção de construir uma relação de respeito e afetividade com eles. O ED foi percebido pelas estagiárias como uma rara oportunidade em que puderam aprender sobre a prática docente, haja vista que não há disciplinas de formação pedagógica no programa de pós-graduação em tela, cuja principal ênfase é a pesquisa. Dessa forma, o ED proporcionou apreender e experienciar os aspectos pedagógicos, técnico-científicos e éticos inerentes à prática docente (Amorim et al., 2020).

A8 apresenta uma pesquisa realizada por meio de entrevista semiestruturada com 12 pós-graduandos concluintes de ED. O material resultante das entrevistas foi tratado por análise de conteúdo, indicando que o ED foi objetivado como o lugar da prática, representado sob cinco dimensões: o estágio como treino do pós-graduando para a docência; o estágio como espaço de relação interpessoal, incluindo a relação professor-estudante; o estágio como experiência, como atividade que agrega vivências aos docentes iniciantes, contribuindo para que o pós-graduando, ao assumir a função de professor, atue com segurança e competência; o estágio como aprendizagem, como oportunidade de o estagiário construir aprendizagens para atuar nessa profissão; o estágio percebido como um desafio menor do que o esperado (Freitas \& Ribeiro, 2021). 
As autoras salientam que a aprendizagem da docência é um processo que precisa ser priorizado na pós-graduação, que ainda carece de espaços institucionais voltados à construção coletiva da identidade docente, nos quais estagiários e professores possam compartilhar experiências, dificuldades, dúvidas e cooperação, no sentido de construírem saberes pedagógicos e desenvolverem um perfil docente. Ainda, ponderam que o ED pode ser esse lócus privilegiado, que garanta um ambiente de formação ao professor do ensino superior. Nesse contexto, as autoras destacam que o estágio, na perspectiva de treino, descaracteriza a dimensão epistêmica e reflexiva dessa atividade formativa. Além disso, em contraponto à representação da docência como desafio menor, foi sublinhado que ser professor não é coisa pouca, afirmando-se que é imprescindível a incorporação de atividades avaliativas do estágio e do programa, assim como avaliações institucionais, a fim de qualificar este componente formativo (Freitas \& Ribeiro, 2021).

\section{Resultados e Discussão}

$\mathrm{Na}$ análise da literatura incluída nesta revisão, identificou-se potências, fragilidades, desafios e oportunidades do ED para a formação de professores da educação superior em saúde. Os achados desta análise são apresentados (Figura 2) e discutidos a seguir.

Figura 2. Potências, fragilidades, desafios e oportunidades do estágio de docência.

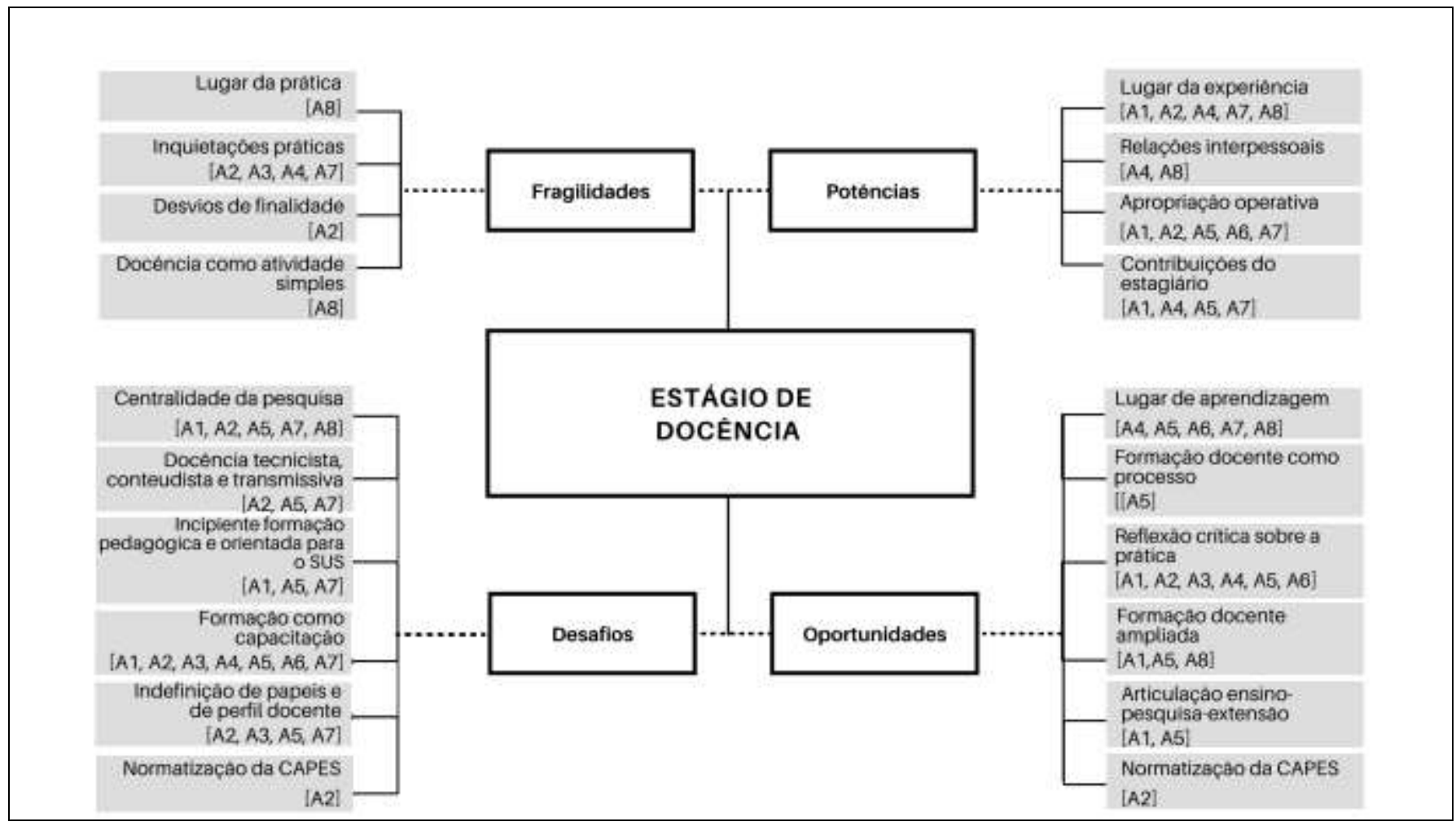

Fonte: Elaboração da autora (2021).

Os estudos analisados são unânimes ao concluir pela importância do ED, reconhecendo contribuições para a qualificação e a formação docente dos pós-graduandos. A despeito disso, a análise da literatura evidenciou espaços para a proposição de avanços. É o que se pretende explicitar com a discussão que segue. 


\subsection{Fragilidades e desafios: indicadores dos limites do estágio de docência na formação de professores para a educação superior em saúde}

A começar pelas fragilidades identificadas, aponta-se que o ED surge, da análise, como lugar da prática, como momento de treino ou ensaio da docência, fragilidade que se desdobra em outras, provocando inquietações práticas, as quais, certamente, são importantes e precisam ser levadas em conta, mas representam uma ínfima parte do que seja o quefazer do professor. Mais do que isso, em elevando-se o tensionamento da dimensão da prática, pode-se chegar a desvios de finalidade do ED. Pondera-se que estas fragilidades são as bases sobre as quais se instalam práticas de ED burocratizadas, em que os pósgraduandos, assumindo posições coadjuvantes, reproduzem fazeres, sem questionar, tornando-se tarefeiros a serviço do professor supervisor, tomado como modelo que buscam imitar. Pela naturalização dessas fragilidades, podem ser explicadas percepções da docência como atividade simples - como se ser professor fosse algo simples ou de menor valor social. Esse cenário exacerba uma desvalorização da docência e do professor, além de reforçar uma desprofissionalização da docência.

Propõe-se que, se a finalidade é preparar para a docência com vistas à qualificação do ensino de graduação (Brasil, 2010a, 2017), é fundamental, como um primeiro aspecto a ser considerado, que o ED supere a fragilidade da condição de lugar da prática e se consolide como potência formativa. Dito de outra forma, é fundante que, no ED, os sujeitos descolem da esfera imediata da prática, do senso comum que habita a reprodução e a imitação acrítica de modelos, para alçarem a uma experiência significativa da docência pela via da reflexão teoricamente fundamentada sobre a ação, conforme nos ensina Freire (2016, p. 31):

A curiosidade ingênua, do que resulta indiscutivelmente um certo saber, não importa que metodicamente desrigoroso, é a que caracteriza o senso comum. O saber de pura experiência [concreta, prática] feito. Pensar certo, do ponto de vista do professor, tanto implica o respeito ao senso comum no processo de sua necessária superação quanto o respeito e o estímulo à capacidade criadora do educando. Implica o compromisso da educadora com a consciência crítica do educando cuja 'promoção' da ingenuidade não se faz automaticamente.

Este tema será retomado mais a frente, no texto, articulando fragilidades e potências do ED. Por ora, em seguimento à abordagem dos achados da análise da literatura, sublinha-se os desafios identificados, que se situam imbricados, em uma complexa teia, às fragilidades discutidas. Um primeiro desafio, nuclear no contexto deste estudo, refere-se à centralidade da pesquisa na pós-graduação. Esta centralidade se manifesta na noção, em certa medida já naturalizada, de que a titulação conferida pela pós-graduação - cujo requisito primordial é a realização de pesquisa - contempla uma formação docente adequada, evidenciando uma concepção de pesquisa como essência do trabalho docente e consolidando a formação de pesquisadores como função social da pós-graduação. Frente a esta centralidade, fica secundarizada a formação de professores. Há que se elucidar que não se trata, aqui, de negar a relevância da pesquisa para a docência, nem de reclamar por uma inversão dessa lógica, deslocando a centralidade da pós-graduação para a formação docente. Ao contrário, o que se propõe é a busca por uma unidade, por uma perspectiva de complementaridade entre formação de pesquisadores e de professores na pós-graduação. Assume-se, nesta direção, o pensamento freireano, que afirma a importância do saber da pesquisa para a docência:

[...] o que há de pesquisador no professor não é uma qualidade ou uma forma de ser ou de atuar que se acrescente à de ensinar. Faz parte da natureza da prática docente a indagação, a busca, a pesquisa. O de que se precisa é que, em sua formação permanente, o professor se perceba e se assuma, porque professor, como pesquisador.” (Freire, 2016, p. 30).

Isso significa que a formação do professor precisa promover a atitude de quem, enquanto ensina, continua buscando e procurando, em um processo permanente de inquietação e curiosidade epistemológica, em direção do pensar certo: "Pesquiso para conhecer o que ainda não conheço e comunicar ou anunciar a novidade" (Freire, 2016, p. 31). O autor complementa, reforçando que pesquisar, buscar o novo, é compromisso do professor com sua competência profissional e, por isso, no 
processo de formação permanente, é importante que o professor compreenda que ensino e pesquisa são "quefazeres que se encontram um no corpo do outro" (Freire, 2016, p. 30). Dessa forma, pondera-se que esse desafio possa ser superado pela relativização da centralidade da pesquisa na pós-graduação, rumo à construção de uma relação de unidade indissociável, de superação por incorporação.

Um segundo desafio diz respeito a uma concepção, dominante na área da saúde, de docência tecnicista, conteudista e transmissiva, que resulta em uma percepção do papel do professor como replicador de conteúdo e do ensino como transmissão de informações. De certa forma, pode-se atribuir esta concepção à própria centralidade da pesquisa na pós-graduação, à medida em que parece restar ao ensino a tarefa de transferir (ou repassar) aos estudantes, por meio do professor, os conhecimentos produzidos pela pesquisa, em uma dinâmica de ensino bancário, em que a ação do professor é a de depositar conteúdos nos estudantes (Freire, 2015). Para além disso, essa concepção de docência pode estar imbricada com uma visão dominante - em particular, na área da saúde - de ciência positiva e neutra, o que é corroborado também por Freire, quando denuncia que

A tarefa da educadora ou do educador seria demasiado fácil se se reduzisse ao ensino de conteúdos que nem sequer precisariam de ser tratados assepticamente e assepticamente 'transmitidos' aos educandos, porque, enquanto conteúdos de uma ciência neutra, já eram em si assépticos. O educador neste caso não tinha por que, ao menos, se preocupar ou se esforçar por ser decente, ético, a não ser quanto à sua capacitação. Sujeito de uma prática neutra não tinha outra coisa a fazer senão 'transferir conhecimento' também neutro. (Freire, 2018, pp. 107-108).

Daí desdobra-se um terceiro desafio, recorrente nos estudos analisados, relativo à formação docente como capacitação. Ou seja, se o professor é aquele cuja ação está centrada em produzir (ou em consumir e repassar) pesquisa, então faz sentido que sua formação seja concebida dentro dos limites da capacitação (objetiva, operativa), de forma a tornar o professor alguém capaz de transferir eficazmente aos estudantes conhecimentos produzidos por outrem. Neste ponto, convém elucidar que a palavra capacitação significa "ação ou efeito de capacitar, de tornar capaz [...]. Preparação, ensino, conhecimentos dados a alguém para que essa pessoa desenvolva alguma atividade especializada" (Dicio, 2021, parágrafo único, grifo nosso). No entanto, cabe sublinhar o que aponta Freire sobre a docência, atividade que requer o desenvolvimento de um conjunto de saberes técnico-científicos, ético-políticos, conceituais, culturais, relacionais e atitudinais. Não se trata apenas de capacitação ou de instrumentalização:

A prática educativa implica ainda processos, técnicas, fins, expectativas, desejos, frustrações, a tensão permanente entre prática e teoria, entre liberdade e autoridade, cuja exacerbação, não importa de qual delas, não pode ser aceita numa perspectiva democrática, avessa tanto ao autoritarismo quanto à licenciosidade. $\mathrm{O}$ educador ou a educadora crítica, exigente, coerente, no exercício de sua reflexão sobre a prática educativa ou no exercício da própria prática, sempre a entende em sua totalidade. Não centra a prática educativa, por exemplo, nem no educando, nem no educador, nem no conteúdo, nem nos métodos, mas a compreende nas relações de seus vários componentes, no uso coerente por parte do educador ou da educadora dos materiais, dos métodos, das técnicas (Freire, 2018, p. 151).

A respeito disso, Freire ainda afirma que há um saber primeiro, que é premissa para todos os demais e que concerne a "saber que ensinar não é transferir conhecimento, mas criar as possibilidades para a sua própria produção ou a sua construção" (Freire, 2016, p. 47, grifo do autor). Concordando com essa posição, e em contraponto à noção de capacitação ligada à externalidade de algo que é dado ou de um processo que torna alguém capaz para a docência, que torna alguém professor -, defende-se uma outra ideia de formação, como um processo de apropriação e de desenvolvimento de saberes docentes que se dá sobre as bases da reflexão crítica sobre a prática, o que depende de fundamentação teórico-metodológica, em um esforço intencionado a evitar, conforme alerta Freire, que a teoria se torne "blá-blá-blá e a prática, ativismo" (Freire, 2016, p. 24). 
A esse respeito, exacerbando o cenário delineado, emerge da análise um quarto desafio, referente à incipiente formação pedagógica e orientada para o SUS, revelada no fato de que a formação docente, aqui estudada no contexto do ED, carece de base teórica pedagógica e, para além disso, não tem estado orientada pelo perfil de egresso que a graduação em saúde (onde o futuro professor irá atuar) pretende alcançar, nem pautada pela realidade do sistema de saúde. Esse, a nosso juízo, é um desafio relevante a ser superado se o que se pretende é qualificar a formação de professores para a educação superior em saúde como um requisito para a formação de profissionais em consonância com os princípios do SUS, com vistas a consolidar o sistema e contribuir para a garantia do direito à saúde.

Também como desafio surge a indefinição de papeis e de perfil docente. Neste sentido, constata-se uma indefinição dos papeis do pós-graduando e do professor supervisor no âmbito do ED e uma falta de parâmetros indicativos do perfil docente esperado dos processos de formação. Estes elementos interferem no desenvolvimento do ED na medida em que o primeiro compromete a legitimidade e a construção da autonomia do estagiário (que não se percebe e não é percebido nem como professor, nem como aluno) e o segundo resulta em uma lacuna ou falta de orientação sobre o que se pretende alcançar. Dito de outra forma, a formação docente fica comprometida quando não se tem definido quem é o professor que atende às especificidades da área da saúde. E é isso o que ocorre quando não há explicitação de um perfil docente e quando o estagiário fica relegado a uma posição coadjuvante, tarefeira.

Assim, fica reforçada a ideia de que o saber disciplinar específico de um profissional da saúde é o que basta para que ele se torne professor. Essa ideia, por sua vez, reforça algumas outras: a de que ensinar é transmitir (ou transferir) conhecimentos, a de que não é preciso (para um profissional da saúde) formação pedagógica, a de que formação docente é sinônimo de capacitação ou treinamento. Ou seja, há uma coerência desfavorável na dinâmica segundo a qual o ED vem sendo desenvolvido e que, portanto, precisa ser rompida, de forma que ele efetivamente represente uma potência para a formação docente para a educação superior em saúde.

Finalmente, há que se discutir um elemento, apresentado pela literatura como um desafio para a realização do ED como processo de formação docente, mas que, a nosso juízo, reúne em si, dialeticamente, um desafio e uma oportunidade. Trata-se da normatização da CAPES sobre o ED. Na literatura, esse elemento surge em sua negatividade, sob alegações de que a flexibilização das normas para a realização do ED permite que diferentes IES e programas de pós-graduação o materializem de formas muito variadas, não atendendo, na maior parte das situações, o que se espera de um processo formativo qualificado. Além dessa, uma outra alegação diz respeito ao fato de que, embora a CAPES atribua à pós-graduação tanto a formação de pesquisadores quanto a de professores para a educação superior, a agência desequilibra essa relação ao considerar, tão somente, indicadores relativos à pesquisa e à produção científica na avaliação dos programas de pós-graduação. Concordando com essa última alegação, que evidencia uma postura contraditória da CAPES, em prejuízo da formação docente e da valorização da profissão de professor, discordamos, aqui, daquela que aponta a flexibilidade como desafio para o ED. Esse aspecto, a nosso juízo, é uma oportunidade, e será retomado na sequência desta discussão.

\subsection{Potências e oportunidades: expressão das potencialidades do estágio de docência na formação de professores para a educação superior em saúde}

Entre as potências identificadas na análise desenvolvida, o ED surge como lugar da experiência de ser professor. Para além disso, convém retomar que a análise também apontou o ED como lugar da prática. Embora essas duas categorias, aqui identificadas, respectivamente, como potência e como fragilidade, possam parecer se sobrepor, argumenta-se que, no caso em tela, a experiência se vale da prática, incorporando-a e superando-a. Isso significa dizer que a prática, per se, não representa uma experiência, posto que, conforme alerta Bondía (2002, p. 21), "a experiência é o que nos passa, o que nos acontece, o que nos toca" e "ao nos passar nos forma e nos transforma" (Bondía, 2002, p. 26). Sob essa ótica, é preciso que, a priori, os 
sujeitos envolvidos com o ED se abram à experiência, se coloquem disponíveis a que algo lhes passe, se tornem espaços do acontecer, sujeitos da experiência (Bondía, 2002). É preciso tomar a experiência concreta (ação, prática) tão somente como um ponto de partida, que dispare um movimento de reflexão, análise e nova prática (nova ação, experiência significativa) (Romão, Rocha, \& Sá, 2021). Logo, há que se adotar uma atitude de abertura essencial e disponibilidade fundamental (Bondia, 2002) a esse processo pelo qual é possível superar a experiência concreta (prática), elevando-a à condição de experiência significativa de aprendizagem (Romão et al., 2021).

Nesse sentido é que se argumenta que a prática, embora central no processo de aprendizagem, precisa ser superada por incorporação - pela experiência. Quando isso não ocorre, o ED se torna um fim em si mesmo, burocrático, espaço de reprodução de práticas, de imitação de modelos, e sua realização assume um sentido de cumprimento de normas e requisitos para a titulação na pós-graduação. A esse respeito, Freire (2016, p. 31) sustenta que "O saber que a prática docente espontânea ou quase espontânea, 'desarmada', indiscutivelmente produz é um saber ingênuo, um saber de experiência [concreta, prática] feito, a que falta a rigorosidade metódica que caracteriza a curiosidade epistemológica do sujeito.” (Freire, 2016, p. 39).

Nessa perspectiva, como lugar da experiência, o ED constitui importante etapa do processo de formação do estudante de pós-graduação, repercutindo em outras potências ao ser desenvolvida sobre as bases da construção de relações interpessoais e proporcionando um movimento não só de apropriação operativa da docência como de desenvolvimento pessoal, no qual incidem, também, contribuições do estagiário. O que se argumenta é que uma experiência é uma situação significativa, de (re)conhecimento, criação e recriação da realidade, que se processa no confronto de ideias e resulta na produção de novos sentidos (Pimentel, 2007). Ao experienciar a prática pedagógica, o pós-graduando vivencia a complexa rede de relações professor-estudante-professor, em um processo de troca e construção coletiva que propicia desenvolvimento a todos os envolvidos, em função da própria presença ativa e desafiadora do estagiário, de sua aproximação com a realidade da prática social dos estudantes de graduação e dos aportes que ele pode proporcionar pelo compartilhamento de conhecimentos apreendidos na pós-graduação. Segundo Freire (2016), o fortalecimento de uma rede de relações respeitosas, éticas, democráticas, encharcadas de amorosidade e confiança é a base para o conhecer. Isso é especialmente importante no âmbito do ED, quando o estagiário, realizando suas primeiras aprendizagens sobre o ser professor, começa a se apropriar da docência pela sua dimensão objetiva, operativa - importante, certamente, mas na qual não se esgota a complexidade da formação docente:

Creio poder afirmar, na altura destas considerações, que toda prática educativa demanda a existência de sujeitos, um que, ensinando, aprende, outro que, aprendendo, ensina, daí o seu cunho gnosiológico; a existência de objetos, conteúdos a serem ensinados e aprendidos; envolve o uso de métodos, de técnicas, de materiais; implica, em função de seu caráter diretivo, sonhos, utopias, ideais (Freire, 2016, p. 68, grifo do autor).

Uma última categoria adotada na análise da literatura tange às oportunidades identificadas a partir dos estudos para que o ED se constitua como espaço relevante de formação de professores na saúde. Assume-se que as oportunidades contêm as possibilidades de avanço do ED na direção de sua finalidade de qualificar a formação docente. Sob essa perspectiva, foram identificadas algumas oportunidades principais, como a possibilidade de constituir o ED como lugar de aprendizagem, mais do que como lugar da experiência e ainda mais do que como lugar da prática. Conceber o ED como lugar de aprendizagem implica tomar a prática como ponto de partida para o desenvolvimento do pensamento, de forma que, ao ir se desprendendo da imediaticidade da prática, o pensamento se vá afirmando, processualmente, como atividade teórica (Martins, 2015). Em outras palavras, para elevar o ED da condição de lugar da prática para a de lugar de aprendizagem, é essencial que seja superada a perspectiva de imitação ou reprodução de modelos (própria da dimensão da prática), passando pela de reflexão crítica e teoricamente embasada sobre essa prática (dimensão da experiência) (Romão et al., 2021) para se alcançar a da incorporação 
de um conhecimento amplo e generalizado sobre a realidade da prática (dimensão da aprendizagem), em um movimento ancorado por operações superiores de pensamento (análise, síntese, generalização) (Martins, 2015).

Sob essa ótica, a assunção do ED como um processo pautado pela reflexão crítica sobre a prática, sustentado por bases teóricas e desenvolvido na interação dialógica com pares e professores, representa ainda uma oportunidade de formação docente ampliada, em que pós-graduandos e professores supervisores podem aprender juntos, em colaboração, com repercussões na qualificação da educação superior. Essa qualificação caminha por duas vias: a dos estagiários (futuros professores) e a dos professores da graduação, supervisores do ED.

A prática docente crítica, implicante do pensar certo, envolve o movimento dinâmico, dialético, entre o fazer e o pensar sobre o fazer. [...]. Por isso, é fundamental que, na prática da formação docente, o aprendiz de educador assuma que o indispensável pensar certo não é presente dos deuses nem se acha nos guias de professores que iluminados intelectuais escrevem desde o centro do poder, mas, pelo contrário, o pensar certo que supera o ingênuo tem que ser produzido pelo próprio aprendiz em comunhão com o professor formador. [...]. Por isso é que, na formação permanente dos professores, o momento fundamental é o da reflexão crítica sobre a prática. É pensando criticamente a prática de hoje ou de ontem que se pode melhorar a próxima prática (Freire, 2016, pp. 39-40, grifos nossos).

Pondera-se que, neste percurso, que é compartilhado, pode ser construída uma efetiva integração da graduação com a pós-graduação. É nesse contexto que o ED pode se constituir como um espaço-tempo em que pós-graduandos e supervisores desenvolvem saberes para e sobre a docência, conscientizando-se da formação docente como processo contínuo, como um compromisso com um quefazer que não se esgota no estágio - antes, principalmente, se inicia nele. Isso só é possível quando os sujeitos, coletivamente, conscientizam-se do próprio inacabamento, pois é o saber-se inconcluso que abre espaço para o desenvolvimento contínuo, a aprendizagem, a disponibilidade à mudança. Quando se reconhecem como seres inacabados, abertos ao novo, ao outro, à reflexão, a ouvir e anunciar, conscientes da própria inconclusão - exclusividade humana - os sujeitos são capazes de fazer escolhas e de intervir no mundo. Ou seja, saber-se condicionado pelo limite do próprio conhecimento em um dado momento histórico move o sujeito para a busca, para o saber, para o ser mais. Por isso, o saber-se inacabado, inconcluso, é um saber fundante da formação docente (Freire, 2016). Esse saber, além de base para a concepção da formação docente como processo, também o é para a reflexão crítica sobre a prática, pois apenas quem se assume inconcluso pode reconhecer-se em processo permanente de formação, tomando a reflexão crítica sobre a própria prática como exercício para melhorar a próxima prática (Freire. 2016).

$\mathrm{Na}$ direção de oferecer elementos para, assim, qualificar o ED, a literatura analisada indica algumas alternativas, como a implantação, na pós-graduação, de preparação pedagógica prévia ao ED, sob a forma de disciplinas, por exemplo. Nessas condições, pode se proporcionar aos estagiários apropriação de bases teóricas - para além das operativas - que sustentem a reflexão sobre a prática, assim como debate sobre questões caras à docência, tais como o papel mediador do professor e sua interação dialógica com os estudantes, no trato com a tensão do par dialético liberdade-autoridade. Essa tensão pode assumir uma dimensão importante, especialmente frente ao desafio, já citado, da indefinição de papeis no âmbito do ED. Essa indefinição compromete não apenas a legitimidade do estagiário, como também a construção de sua autonomia e de uma compreensão ampliada sobre o ser professor. A esse propósito, Freire anuncia que ensinar exige o saber do trato com a tensão liberdade- autoridade, em favor do equilíbrio da liberdade de estudantes e professores para a construção da autonomia de ambos, em relações respeitosas, éticas e democráticas, evitando-se saídas que escapem pela via da licenciosidade. Argumenta Freire que é na oportunidade contida na escolha, na decisão, no errar e aprender, no ponderar e assumir as consequências de cada escolha, que se constitui a autonomia e se fortalece a responsabilidade de cada um com seu processo de ser mais. "É neste sentido que uma pedagogia da autonomia tem de estar centrada em experiências estimuladoras da decisão e da responsabilidade, vale dizer, em experiências respeitosas da liberdade" (Freire, 2016, p. 105). 
Prosseguindo, e considerando o desafio, posto pela literatura, da centralidade da pesquisa na pós-graduação, destacase a oportunidade que, dialeticamente, aí também reside, de articulação ensino-pesquisa-extensão. Sob esse prisma, o ED pode se constituir como espaço de pesquisa sobre a docência para o pós-graduando estagiário e/ou para o professor supervisor, e ainda pode ser explorado para refletir - estagiários e professores, em diálogo - sobre a articulação ensino-pesquisa-extensão, na medida em que a pesquisa fundamenta a prática baseada em evidências e fornece elementos para a atualização técnicocientífica dos docentes. Abre-se espaço, assim, para ampliar a incorporação da ciência na prática social, o que também pode suscitar no pós-graduando uma visão diferenciada sobre a relevância de suas próprias pesquisas, favorecendo o impacto social da pós-graduação.

Finalmente, destaca-se, como oportunidade, um aspecto específico da normatização da CAPES: a flexibilização das normas para a realização do ED. Argumenta-se que essa flexibilidade é precisamente o que permite a cada IES conduzir o ED em acordo com as condições e limites de sua realidade, tendo como horizonte maximizar a potência deste recurso para o processo de formação docente e, por conseguinte, para a qualificação da educação superior em saúde.

Se tomado sob as premissas aqui discutidas, o estágio de docência pode, a nosso juízo, superar os desafios que o ameaçam em sua potência para a formação docente na área da saúde, sempre tendo no horizonte que a docência é profissão, ou seja, atividade que requer formação específica, que não é simples nem se constrói sobre as bases da inspiração, beneficiando-se da incorporação de processos avaliativos das experiências individuais de estágio, dos programas de pós-graduação e das IES.

\section{Considerações Finais}

Este estudo esteve interessado no estágio de docência no âmbito da pós-graduação stricto sensu, sendo desenvolvido, a partir de análise da literatura, com o objetivo de reconhecer seus limites e potencialidades na formação de professores para a educação superior em saúde.

A análise desenvolvida evidenciou, como fragilidades, uma concepção do estágio de docência como lugar da prática, gerando, por consequência, inquietações práticas e desvios de finalidade, ao produzir ideias da docência como atividade simples. Em um nível macro, de ordem estrutural, a literatura indicou desafios - implicados na gênese das fragilidades mencionadas -, quais sejam: uma perspectiva de centralidade da pesquisa na pós-graduação, acompanhada de uma noção de docência tecnicista, conteudista e transmissiva, reforçada por uma incipiente formação pedagógica e orientada para o SUS, situando, predominantemente, a formação docente como capacitação, contexto exacerbado pela indefinição de papeis e de perfil docente almejado.

Contudo, da análise, também emergiram potências, relativas à concepção do estágio de docência como lugar da experiência, permeado pela construção de relações interpessoais, constituindo-se como espaço-tempo que proporciona as primeiras vivências de apropriação operativa da docência e que se beneficia de importantes contribuições do estagiário. Como oportunidades, foram constatadas uma compreensão do estágio de docência como lugar de aprendizagem, com base em um movimento de reflexão crítica sobre a prática e de entendimento da formação docente como processo, abrindo espaço para uma formação docente ampliada e para o fortalecimento da articulação ensino-pesquisa-extensão.

Além destes elementos, a análise da literatura apontou, como desafio, a normatização da CAPES sobre o estágio de docência, dada a irrelevância que a formação docente assume no sistema de avaliação da pós-graduação stricto sensu. No entanto, pondera-se que, dialeticamente, a normatização da CAPES também representa uma oportunidade para a qualificação do estágio de docência, na medida em que oferece, às instituições de ensino superior, relativa flexibilidade para sua operacionalização e regulação interna, em consonância com as diversas realidades locais.

Dos elementos apresentados, argumenta-se que a aprendizagem da docência é um processo complexo que reclama por priorização na pós-graduação stricto sensu, configurando diversos objetos de pesquisa possíveis, dos quais os sujeitos possam 
se acercar a partir de diferentes abordagens teórico-metodológicas. Produzir conhecimento sobre a docência - e, neste contexto, sobre o estágio de docência - contribuirá, certamente, para a construção de caminhos que descortinem horizontes mais promissores à formação de professores comprometidos com a consolidação e o fortalecimento do SUS por meio da qualificação da educação superior em saúde. A produção de novos e mais robustos conhecimentos sobre a docência e o estágio de docência na saúde pode repercutir sob a forma de alternativas que contemplem uma formação docente ampliada, integrando graduação e pós-graduação e despertando um olhar mais atento da CAPES à valoração da formação de professores no modelo de avaliação da pós-graduação.

À guisa de conclusão, pondera-se que, nestas condições, a pós-graduação alcançaria um novo patamar de impacto social. Este - em coerência com a teoria que suporta este estudo - é o inédito viável que colocamos em pauta para a continuidade deste debate, que consideramos inadiável frente a sua relevância.

\section{Referências}

Alves, L. R., Giacomini, M. A., Teixeira, V. M., Henriques, S. H., \& Chaves, L. D. P. (2019). Reflections on graduate professor training. Escola Anna Nery, 23(3), e20180366. 10.1590/2177-9465-EAN-2018-0366.

Alves, S. M., \& Teo, C. R. P. A. (2020). O ativo das metodologias ativas: contribuições da Teoria Histórico-Cultural para os processos de ensinar e aprender na educação superior. Educação em Revista, 36, e229610. 10.1590/0102-4698229619.

Amorim, T. R. S., Pessoa, M. C. B., \& Alberto, M. F. P. (2020). Aprendendo a ser docente: relato de experiência em estágio de docência. Gerais: Revista Interinstitucional de Psicologia, 13(3), e15241. 10.36298/gerais202013e15241.

Angelim, R. C. M., Brandão, B. M. G. M., Pereira, V. M. A. O., Freire, D. A., \& Abrão, F. M. S. (2019). Educação à distância no ensino superior: relato de experiência em estágio de docência. Revista de Enfermagem do Centro Oeste Mineiro, 9, e2672. 10.19175/recom.v9i0.2672.

Bondía, J. 1. (2002). Notas sobre a experiência e o saber da experiência. Revista Brasileira de Educação, 19, 20-28. 10.1590/S1413-24782002000100003.

Braga, N. L., Pinheiro, N. P., \& Feitosa, L. B. (2016). Estágio em docência: o relato de experiência como recurso necessário na avaliação da aprendizagem. Caminho Aberto - Revista de Extensão do IFSC, 3(5), 66-70.

Brasil. (1988). Constituição da República Federativa do Brasil, de 05 de outubro de 1988. http://www.planalto.gov.br/ccivil_03/constituicao/constituicao.htm.

Brasil. (1990). Lei n. 8080 de 19 de setembro de 1990. Dispõe sobre os princípios e diretrizes do Sistema Único de Saúde. http://www.planalto.gov.br/ccivil_03/leis/18080.htm.

Brasil. (1999). Ofício CAPES Circular n. 028, de 12 de novembro de 1999. Institui a obrigatoriedade de realização de Estágio de Docência na graduação para bolsistas de pós-graduação. http://www.jusbrasil.com.br/diarios/1468634/pg-61-secao-3-diario-oficial-da-uniao-dou-de-12-11-1999.

Brasil. (2001a). Resolução CNE/CES n. 3, de 07 de novembro de 2001. Institui Diretrizes Curriculares Nacionais do Curso de Graduação em Enfermagem. http://portal.mec.gov.br/cne/arquivos/pdf/CES03.pdf.

Brasil. (2001b). Resolução CNE/CES n. 4, de 07 de novembro de 2001. Institui Diretrizes Curriculares Nacionais do Curso de Graduação em Medicina. http://portal.mec.gov.br/cne/arquivos/pdf/CES04.pdf.

Brasil. (2001c). Resolução CNE/CES n. 5, de 07 de novembro de 2001. Institui Diretrizes Curriculares Nacionais do Curso de Graduação em Nutrição. http://portal.mec.gov.br/cne/arquivos/pdf/CES05.pdf.

Brasil. (2002). Portaria $N^{o}$ 52, de 26 de setembro de 2002. Aprova o regulamento do Programa de Demanda Social. https://www.gov.br/capes/pt-br/centraisde-conteudo/portaria-52-regulamento-ds-pdf.

Brasil. (2005). Portaria Interministerial $N^{o}$ 2.101, de 3 de novembro de 2005. Institui o Programa Nacional de Reorientação da Formação Profissional em Saúde - Pró-Saúde. http://www.abem-educmed.org.br/publicacoes/boletim_virtual/volume_10/portaria_pro_saude.pdf.

Brasil. (2008). Portaria interministerial $N^{o}$. 1.802, de 26 de agosto de 2008. Institui o Programa de Educação pelo Trabalho para a Saúde - PET - Saúde. https://bvsms.saude.gov.br/bvs/saudelegis/gm/2008/pri1802_26_08_2008.html.

Brasil. (2010a). Plano Nacional de Pós-Graduação - PNPG 2011-2020 (Vols. 1-2). Capes. https://www.gov.br/capes/pt-br/acesso-ainformacao/institucional/plano-nacional-de-pos-graduacao.

Brasil. (2010b). Portaria $N^{o} 76$, de 14 de abril de 2010. Aprova o novo regulamento do Programa de Demanda Social. http://www.capes.gov.br/images/stories/download/legislacao/Portaria_076_RegulamentoDS.pdf.

Brasil. (2012). Portaria $N^{o} 181$, de 18 de dezembro de 2012. Aprova o regulamento do Programa de Suporte à Pós-Graduação de Instituições de Ensino Particulares, para disciplinar o fomento do programa a partir do exercício de 2013. http://cad.capes.gov.br/ato-administrativo-detalhar?idAtoAdmElastic=572.

Brasil. (2017a). Instrumento de avaliação de cursos de graduação presencial e a distância. Inep/MEC. 
Research, Society and Development, v. 10, n. 11, e577101119836, 2021

(CC BY 4.0) | ISSN 2525-3409 | DOI: http://dx.doi.org/10.33448/rsd-v10i11.19836

Brasil. (2017b). Portaria $N^{\circ} 149$, de $1^{\circ}$ de agosto de 2017. Aprova o regulamento do Programa de Suporte à Pós-Graduação de Instituições Comunitárias de Educação Superior, para disciplinar o fomento do programa para as Instituições Comunitárias de Educação Superior - ICES, a partir do exercício de 2017. https://www.in.gov.br/materia/-/asset_publisher/Kujrw0TZC2Mb/content/id/19212855/do1-2017-08-02-portaria-n-149-de-1-de-agosto-de-2017-19212692.

Brasil. (2020a). Lei de Diretrizes e Bases da Educação Nacional (4a ed.). Senado Federal.

Brasil. (2020b). Proposta de Aprimoramento da Avaliação da Pós-Graduação Brasileira para o Quadriênio 2021-2024 - Modelo Multidimensional da Comissão Especial de Acompanhamento do PNPG 2011-2020/Relatório 2019. Capes. https://www.gov.br/capes/pt-br/centrais-de-conteudo/25052020relatorio-final-2019-comissao-pnpg-pdf

Dicio. (2021). Dicionário Online de Português: Capacitação. 7Graus. https://www.dicio.com.br/capacitacao/.

Freire, P. (1991). A educação na cidade. Cortez.

Freire, P. (2015). Pedagogia do oprimido (59a ed.). Paz e Terra.

Freire, P. (2016). Pedagogia da autonomia (53a ed.). Paz e Terra.

Freire, P. (2018). Pedagogia da esperança. (24a ed.). Paz e Terra.

Freitas, D. A., Santos, E. M. S., Lima, L. V. S., Miranda, L. N., Vasconcelos, E. L., \& Nagliate, P. C. (2016). Saberes docentes sobre processo ensinoaprendizagem e sua importância para a formação profissional em saúde. Interface (Botucatu), 20(1), 437-448. 10.1590/1807-57622014.1177.

Freitas, E. N. B., \& Ribeiro, M. L. (2021). O estágio de docência nas representações de estudantes de saúde coletiva. Temas em Educação e Saúde, 17(00), e021006. 10.26673/tes.v17i00.14742.

Friestino, J. K. O., Ferraz, R. O., Fialho, P. M. M., \& Corrêa, C. R. S. (2015). A docência como eixo formador de doutores em saúde coletiva: contribuição do estágio docente. Revista UNIABEU, 8(20), 325-336.

Ganong, L. H. (1987). Integrative reviews of nursing research. Research in Nursing \& Health, 10(1), 1-11. 10.1002/nur.4770100103.

Lima, M. M., Vendruscolo, C., Prado, M. L., \& Reibnitz, K. S. (2015). Estágio de docência na construção de saberes para ensinar: revisão integrativa. Revista de enfermagem UFPE on line, 9(1), 220-227. 10.5205/reuol.6817-60679-1-ED.0901201530.

Martins, L. (2015). A formação social da personalidade do professor: um enfoque vigotskiano (2a ed.). Autores Associados.

Minayo, M. C. S. (2014). O desafio do conhecimento (14a ed.). Hucitech.

Pimentel, A. (2007). A teoria da aprendizagem experiencial como alicerce de estudos sobre desenvolvimento profissional. Estudos de Psicologia, 12(2), 159168. $10.1590 / \mathrm{S} 1413-294 \mathrm{X} 2007000200008$.

Ribeiro, G. M., \& Zanchet, B. M. B. A. (2015). Estágio de docência: possibilidades e limites na formação de professores universitários. Currículo sem Fronteiras, 15(2), 508-526.

Romão, G. S., Rocha, S. R., \& Sá, M. F. S. (2021). A aprendizagem experiencial na residência médica. Femina, v. 49(4), 219-222. 